Pesq. Vet. Bras. 36(11):1059-1066, novembro 2016 DOI: $10.1590 / \mathrm{S} 0100-736 \mathrm{X} 2016001100001$

\title{
Polymorphisms in the Prion Protein Gene of cattle breeds from Brazil ${ }^{1}$
}

\author{
Cristiane C. Sanches ${ }^{2}$, Grácia M.S. Rosinha ${ }^{3}$, Cleber E. Galvão² ${ }^{2}$ Gelson L.D. Feijó ${ }^{3}$, \\ Flábio R. Araújo ${ }^{3}$ and Cleber O. Soares ${ }^{3 *}$
}

\begin{abstract}
Sanches C.C., Rosinha G.M.S., Galvão C.E., Feijó G.L.D., Araújo F.R. \& Soares C.O. 2016. Polymorphisms in the Prion Protein Gene of cattle breeds from Brazil. Pesquisa Veterinária Brasileira 36(11):1059-1066. Programa de Doutorado em Ciência Animal, Universidade Federal do Mato Grosso do Sul, Av. Senador Filinto Müller 2443, Cidade Universitária, Cx. Postal 549, Campo Grande, MS 79070-500, Brazil. E-mail: cleber.soares@embrapa.br

One of the alterations that occur in the PRNP gene in bovines is the insertion/deletion (indel) of base sequences in specific regions, such as indels of 12-base pairs (bp) in intron 1 and of 23- bp in the promoter region. The deletion allele of $23 \mathrm{bp}$ is associated with susceptibility to bovine spongiform encephalopathy (BSE) as well as the presence of the deletion allele of $12 \mathrm{bp}$. In the present study, the variability of nucleotides in the promoter region and intron 1 of the PRNP gene was genotyped for the Angus, Canchim, Nellore and Simmental bovine breeds to identify the genotype profiles of resistance and/or susceptibility to BSE in each animal. Genomic DNA was extracted for amplification of the target regions of the $P R N P$ gene using polymerase chain reaction (PCR) and specific primers. The PCR products were submitted to electrophoresis in agarose gel $3 \%$ and sequencing for genotyping. With the exception of the Angus breed, most breeds exhibited a higher frequency of deletion alleles for $12 \mathrm{bp}$ and $23 \mathrm{bp}$ in comparison to their respective insertion alleles for both regions. These results represent an important contribution to understanding the formation process of the Brazilian herd in relation to bovine PRNP gene polymorphisms.
\end{abstract}

INDEX TERMS: Bovine spongiform encephalopathy, PRNP, prion, indel, cattle, Brazil.

RESUMO.- [Polimorfismos no gene da proteína priônica em bovinos no Brasil.] Uma das mudanças que ocorrem no gene $P R N P$ em bovinos é a inserção e/ou deleção (indels) de sequências de bases, em determinadas regiões como, por exemplo, as indels de 12 pares de bases (pb) no íntron 1 e 23 pb na região promotora. 0 alelo de deleção de 23 pb está relacionado com a suscetibilidade à Encefalopatia Espongiforme Bovina (EEB), assim como a presença do alelo de deleção de $12 \mathrm{pb}$. Neste estudo foi genotipada a variabilidade de nucleotídeos da região promotora e íntron 1 do gene PRNP em bovinos das raças Angus, Canchim, Nelore e Simental, para identificar os perfis genotípicos de resistência e/ou suscetibilidade à EEB de cada animal. Foi re-

\footnotetext{
${ }^{1}$ Received on January 13, 2016.

Accepted for publication on September 14, 2016.

${ }^{2}$ Universidade Federal de Mato Grosso do Sul, Programa de Doutorado em Ciência Animal, Avenida Senador Filinto Müller 2443, Cidade Universitária, Cx. Postal 549, Campo Grande, MS 79070-500, Brazil.

${ }^{3}$ Embrapa Gado de Corte, Sanidade Animal, Av. Rádio Maia 830, Campo Grande, MS 79106-550, Brazil. *Corresponding author: cleber.soares@embrapa.br
}

alizada a extração de DNA genômico para amplificação das regiões alvo do gene $P R N P$, por meio da reação em cadeia de polimerase (PCR) utilizando-se primers específicos. Os produtos da PCR foram submetidos à eletroforese em gel de agarose a $3 \%$, e sequenciamento para a realização da genotipagem. Com exceção da raça Angus, a maioria das raças apresentaram maiores frequências do alelo de deleção tanto para $12 \mathrm{pb}$ como $23 \mathrm{pb}$, em comparação com seus respectivos alelos de inserção, para as duas regiões. Esses resultados abrem caminhos para o conhecimento de como o rebanho brasileiro está sendo formado com relação aos polimorfismos do gene PRNP bovino.

TERMOS DE INDEXAÇÃO: Encefalopatia espongiforme bovina, $P R N P$, prion, polimorfismo, bovinos, Brasil.

\section{INTRODUCTION}

Bovine spongiform encephalopathy (BSE), also known as mad cow disease, is a zoonosis that is part of the transmissible spongiform encephalopathy group (TSEs) (Czarnik et al. 2007). The first cases of BSE occurred in 1985 in dairy 
cattle supplemented with animal origin protein (Wells et al. 1987).

Spongiform encephalopathy remains an issue of great importance to public health due to the discovery of a variant of Creutzfeldt-Jakob disease (vCJD). Efforts have been made to understand the epidemiology of BSE and discover whether this disease breaks through the inter-species barrier and can affect humans, since BSE is capable of causing illness resembling vCJD in primates (Holznagel et al. 2013).

$\mathrm{PrP}^{\mathrm{C}}$ is a normal protein that synthesized from the PRNP gene. This protein is present in the cell membrane of CNS neurons, participate in neural differentiation process remains intact myelin sheaths protecting nerve fibers and has the ability to stabilize synapses that form long-term memories (Aguzzi et al. 2013). In cattle, the PRNP gene is on chromosome 13 in the position Q17 BTA, being a single copy gene with about 2,5 kilobases (kb) containing three exons, the exon encoding the last ORF (open reading frame). The first intron is described for supporting the action of the promoter region and exon 1 contrast can be associated with suppressive activity than the promoter region (Haigh et al. 2007).

$\mathrm{PrP}^{\mathrm{Sc}}$ is an infectious protein and causal agent of several TSEs, such as CJD in humans, BSE in bovines and Scrapie in sheep and goats. The modified protein is toxic to the nervous system and may gradually deposit in the brain causing a fatal spongiform encephalopathies, nervous tissue it causes neuronal loss, abnormal synapse evolving to vacuolization, neuroinflammation and deposition of amyloid fibrils (Aguzzi et al. 2013).

There is evidence of polymorphic changes in the PRNP gene and the risk of the development of transmissible encephalopathies in sheep, humans, deer and mice. Such evidence is currently being studied in bovines. A number of polymorphisms have been described and are associated with genotypes in which animals have a lower risk of developing BSE. The structure of the gene and the major polymorphisms indel shown in Figure 1.

BSE is divided into the classic and atypical types. The development of classic BSE may be associated with the incorporation of meat and bone meal containing $\mathrm{PrP}^{\mathrm{Sc}}$ into the bovine diet (Konold et al. 2012).

One of the alterations that occur in the PRNP gene in bovines is the indel of base sequences in determined regions, such as the indels of 12 base pairs (bp) in intron 1, $23 \mathrm{bp}$ in the promoter region, $14 \mathrm{bp}$ in the 3 ' non-translated region (3' UTR) and $24 \mathrm{bp}$ in the region of repeated octapeptides.

The most relevant are indels of $23 \mathrm{bp}$ and $12 \mathrm{bp}$. The

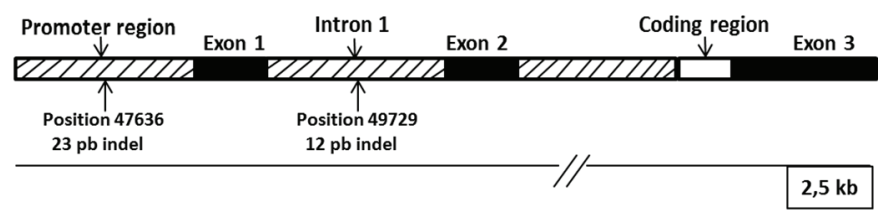

Fig.1. Diagram illustrating the structure of the gene PRNP gene in cattle with approximately $2.5 \mathrm{~kb}$. (a) Description of two major polymorphisms in/del indicated by arrows. (b) Representation of the three exons illustrated by black bars and the coding region shown by the white bar. deletion allele of $23 \mathrm{bp}$ in the promoter region, localized in the region $47636 \mathrm{pb}$ of gene, is associated with a greater risk of the development of susceptibility to BSE. Another genetic factor that may be associated with the possible development of classic BSE is the presence of the deletion allele of $12 \mathrm{bp}$ in intron 1, localized in the region $49729 \mathrm{pb}$ of gene (Juling et al. 2006).

The aim of the present study was to genotype the variability of the nucleotides (indels) in the promoter region and intron 1 of the PRNP gene in the Angus, Canchim, Nelore and Simmental bovine breeds to identify the genotype profiles of resistance and/or susceptibility to BSE in each animal.

\section{MATERIALS AND METHODS}

Samples. For the analyzes of 102 animal breeds of Zebu, European and Brazilian origin were genotyped. Through the Embrapa Beef Cattle breeding program (GENEPLUS) (http://www. geneplus.com.br/) were selected and used 34 breeders Nellore, Zebu breed of Indian origin (Bos indicus tauurus), 26 Angus breeders, European breed of Scottish origin (Bos taurus tauurus), 25 Simmental animals, European breed of Swiss origin (Bos taurus tauurus) and 17 animals Canchim breed in Brazil formed by breeding Charolais breed with zebu breeds (Nellore, Guzera and Indubrasil). Samples of animals from different farms were used in the experiment. These animals have a low degree of kinship ie, coefficient of inbreeding (Fi) between $0 \%$ and $9 \%$, obtained by routines developed in MATLAB.

DNA Extraction. The method described by Olerup \& Zetterquist (1992) was used to extract genomic DNA from leucocytes of animals breeds Angus, Simmental, Canchin and nine animals Nellore. The method described by Zadworny \& Kuhnlein (1990) was used to extract genomic DNA from semen samples from 25 animals Nellore.

Integrity of extracted DNA.The purity of the total DNA from the samples was verified by electrophoresis in agarose gel $0.8 \%$ $\left(\right.$ Promega $^{\circledR}$ ) stained with SYBR Gold (Invitrogen ${ }^{\circledR}$ ) before being analyzed under ultraviolet light in a transluminator (Transluminator Loccus Biotecnologia ${ }^{\circledR}$ ) and photographed with a digital camera using the L. PIX software program (Loccus Biotecnologia ${ }^{\circledR}$ ). The concentration was determined in a spectrophotometer (NanoDrop ${ }^{\circledR}$ ).

Design of primers and amplification of target regions. Specific primers previously described by (Galvão et al. 2012) were used for the detection of the 12-bp indel (prnpBovin12F: 5' - GGT AAA TAG CCG CGT AGT CCT T - 3'; prnpBovin12R: 5' - TCG CCC TTG TTC TTC TGA GC - 3'), amplifying a sequence of $400 \mathrm{bp}$, and for the detection of the 23-bp indel (prnpBovin23F: $5^{\prime}$ - TCC TCT TGG GAC TTC TTA AGC CAG GTA - 3'; prnpBovin23R: 5' - AAG GCA ATA TAG TTC GTG AGG GTT TGA G - 3'), amplifying a sequence of $393 \mathrm{bp}$.

The target regions of the PRNP gene were amplified by polymerase chain reaction (PCR) using from 40 to 60 ng of DNA per reaction of $22 \mu \mathrm{L}$, containing buffer $10 \mathrm{X}, 1.5 \mathrm{mM}$ of $\mathrm{MgCl}_{2}, 0.5 \mathrm{mM}$ of dNTPs, 5 pmol of each primer and one unit of Taq DNA polymerase $\left(\right.$ CenBiot $\left.^{\circledR}\right)$. This was done using specific primers for the analyses of mutations (insertion/deletion) that occurred in the bovine PRNP gene in association with $12 \mathrm{bp}$ and $23 \mathrm{bp}$. Amplification was performed at $94^{\circ} \mathrm{C}$ for 5 minutes for the initial denaturation, 34 cycles of 45 seconds at $94^{\circ} \mathrm{C}$ for denaturation, $58^{\circ} \mathrm{C}$ and $60^{\circ} \mathrm{C}$ for 45 seconds for primer annealing associated with indel 12 and indel 23 , respectively, $72^{\circ} \mathrm{C}$ for 2 minutes for extension, as well as $72^{\circ} \mathrm{C}$ for 5 minutes for the final extension. 
Genotyping. The PCR products were submitted to electrophoresis in agarose gel (Promega ${ }^{\circledR}$ ) at a concentration of $3 \%$. The standard base pair used was $1 \mathrm{~Kb}$ plus Ladder (Invitrogen ${ }^{\circledR}$ ) to aid in the visualization of the height of the bands that resulted from the PCR amplification of the target areas. The gels were submitted to ultraviolet light in a transluminator (Transluminator Loccus Biotecnologia ${ }^{\circledR}$ ) to visualize the amplification and then photographed with a digital camera with the aid of L. PIX software program (Loccus Biotecnologia ${ }^{\circledR}$ ). In the analyses of the gels, animals were classified as homozygous animals with bp insertion bp, homozygous with bp deletion and heterozygous for the indel 12 and indel 23 regions. Once the genotypes of each animal had been obtained, haplotypes and diplotypes were determined.

DNA sequencing. The amplification products were purified with Qiaex II (Qiagen ${ }^{\circledR}$ ) kit .The amplicons were sequenced in a ABI-PRISM 3100 Genetic Analyzer (Applied Biosystems ${ }^{\circledR}$ ), using $2 \mu \mathrm{l}$ of BigDye Terminator v3.1 Cycle Sequencing (RR-100, Applied Biosystems ${ }^{\circledR}$ ), 30 to $45 \eta \mathrm{g}$ of template DNA and $3.2 \rho \mathrm{mol}$ of each primer for a final volume of $10 \mu \mathrm{l}$.

Statistical analysis. Wih the results of the agarose gel analysis, the genotype and allele frequencies were calculated and submitted to the Hardy-Weinberg equilibrium test to determine if the allele frequency remained constant over a number of generations. The chi-square test was used to compare the degree of significance between the genotype and allele frequencies of the breeds. Frequencies were determined for diplotypes and haplotypes. Haplotypes were compared using the linkage disequilibrium test (D') (Lewontin, 1988) to analyze the degree of dependency between haplotypes and the correlation test (r) to assess the degree of mutual relation between the two polymorphic regions that formed the haplotypes.

At times, the quantity of diplotypes from the Simmental, Canchim and Angus breeds had to be estimated to enable the calculation of their frequencies. These diplotypes came from animals that had double heterozygote genotypes, which means ins/del in both polymorphic regions consecutively. The estimates were obtained using conditional probability $(\mathrm{P})$ and the concrete numbers of each haplotype to assign the respective frequencies, as follows: $P(12$ ins.23del $)=n \div N$, in which " $n$ " is the concrete value of the number of animals with this haplotype and " $\mathrm{N}$ " is the concrete sum of all haplotypes. The same calculation was made for other haplotypes: P (12del.23ins); P (12del.23del); P (12ins.23ins). With the results from the haplotype frequencies, the estimated diplotype values were obtained for the animals conditioned to the double heterozygote genotype, as follows:

From this point forward, it was possible to calculate the conditional probability of diplotype 12ins.23del/12del.23ins by subtracting the value found in $\mathrm{P}$ (12ins.23ins/12del.23del) from 100. With the principle of chromosome distribution $(n+n=2 n)$, it was possible to estimate how many haplotypes came from the diplotypes of these double heterozygote animals.

All calculations were performed with the aid of an electronic calculation spreadsheet in silico.

\section{RESULTS}

Figure 2 illustrates the agarose gel electrophoresis (Promega $^{\circledR}$ ) $0.8 \%$ gel, stained with SYBR Gold (Invitrogen), analyzed under UV light transilluminator (Transluminator Loccus Biotecnologia ${ }^{\circledR}$ ) to check the purity and integrity of the genetic material. The extracted DNA obtained showed satisfactory integrity, with concentrations 40-60ng of DNA and $260 / 280$ absorbance values $260 / 280$ ranging between 1.8 and 2.0 recorded by spectrophotometer (NanoDrop ${ }^{\circledR}$ ).

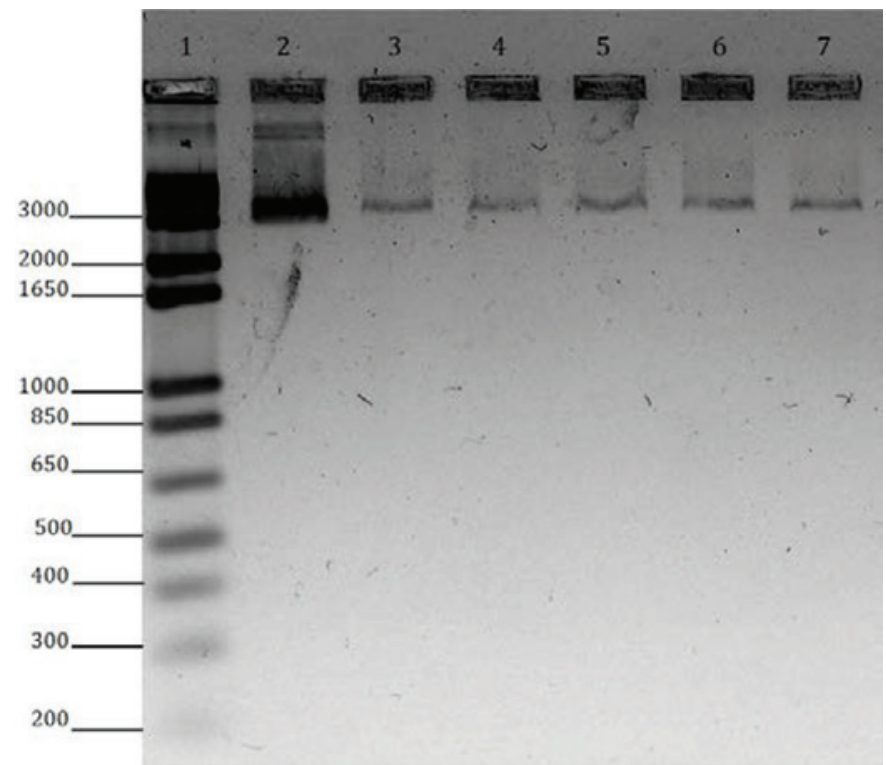

Fig.2. Representative gel. Electrophoretic profile in $0.8 \%$ agarose gel to visualize the integrity of DNA extracted and used in PCR. $1=1 \mathrm{~Kb}$ Plus DNA Ladder Invitrogen, molecular weight standard; Sample 2 = 100 ng Lambda DNA, standard molecular concentration; 3 to 7 Samples of bovine DNA.

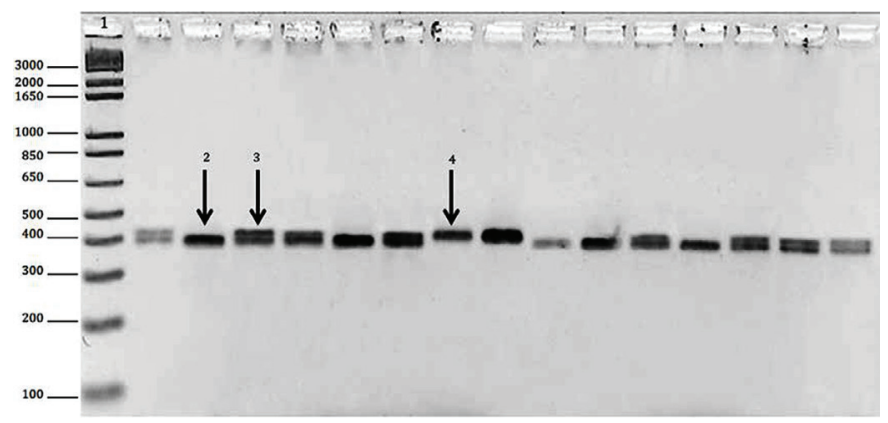

Fig.3. Electrophoresis profile in agarose gel 3\% of PCR of the bovine PRNP gene; 1 = base pair standard; 2 = characteristic band of homozygoous animal with bp deletion; 3 = characteristic band of heterozygous animal; $4=$ characteristic band of homozygous animal with bp insertion.

The pairs of primers used in the PCR to amplify the polymorphic regions performed well. Therefore, it was possible to distinguish homozygous animals with insertion, homozygous animals with deletion and heterozygous animals for intron 1 (12-bp indel) and the promoter region (23-bp indel). Figure 3 displays the electrophoresis profile in agarose gel $3 \%$ of the PCR quality where the formation of bands per fragments occurred, which were amplified by 400 and 393, respectively, for the 12-bp and 23-bp regions. The bands formed at a height of about $400 \mathrm{bp}$, depending on the base pair marker. The presentation of the bands formed in the agarose gel was applied to the 12-bp indel and 23-bp indel, Figure 3 displays the genotype differences in both regions. Through sequencing, it was possible to confirm the genotypic profile observed in each animal by detecting regions of the PRNP gene in which there were indels in intron 1 (12 bp indel) and in the promoter region (23-bp indel) (Fig.4 and Fig.5). 


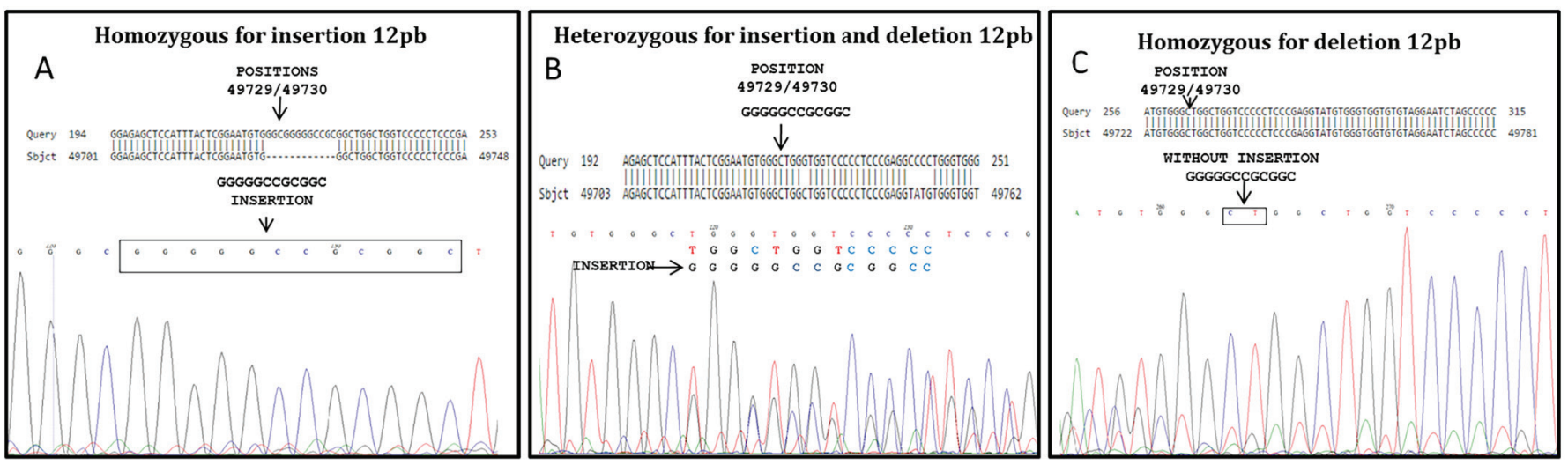

Fig.4. Representative electropherogram. Comparison between polymorphisms in a specific region of the PRNP gene. Alignments made from the PRNP gene AJ298878 access of cattle and deposited in GenBank under electropherograms representing the same region. (A) Bovine homozitogoto, with insertion of $12 \mathrm{bp}$ for both alleles. (B) Bovine heterozygote, with the arrows indicating the position of the $12 \mathrm{bp}$ deletion in one allele sequence and insertion of $12 \mathrm{bp}$ on the other allele. (C) Bovine homozygous with $12 \mathrm{bp}$ deletion in both alleles.

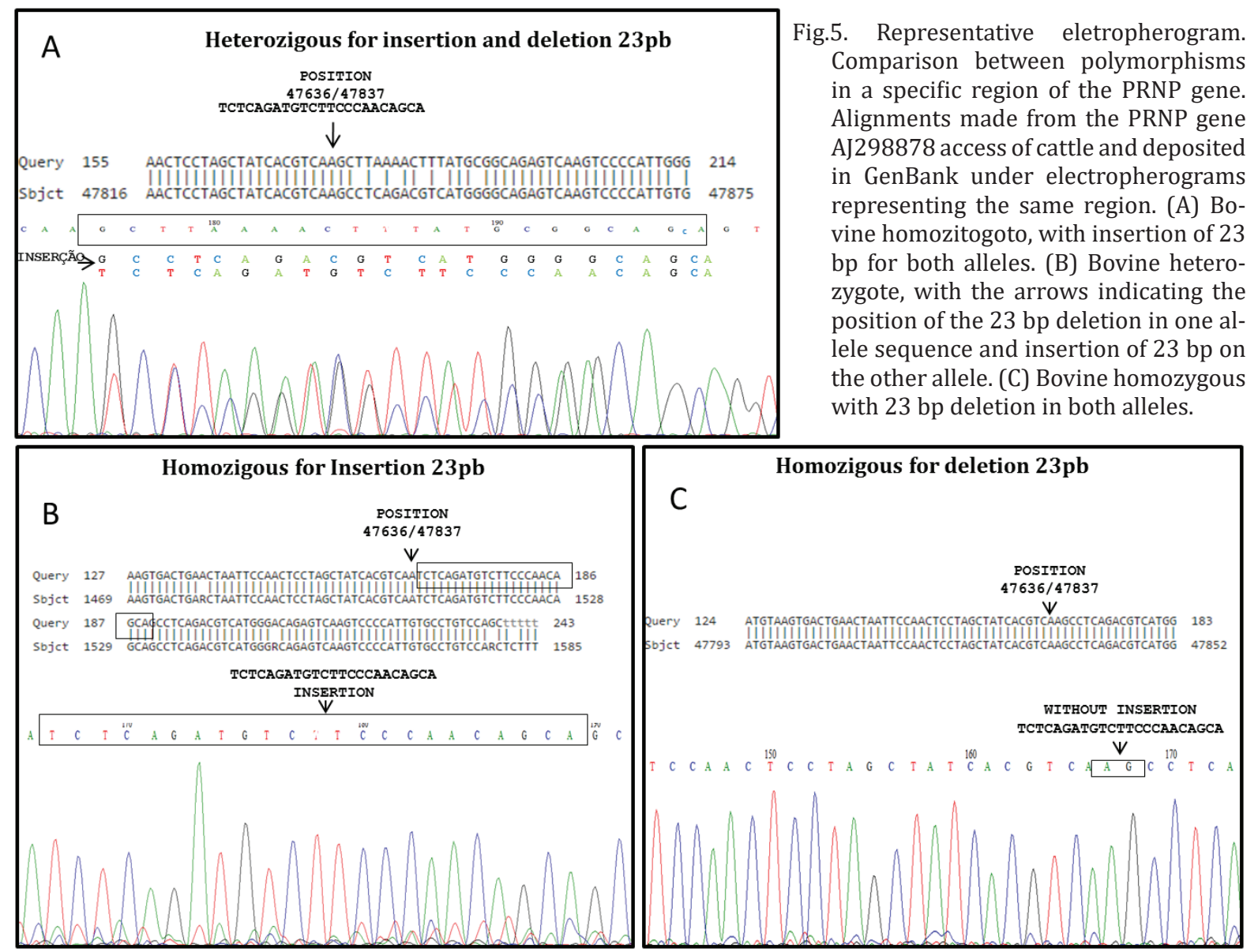

The genotype and allele frequencies were calculated using the analysis of the electrophoresis profile of each animal in agarose gel for both polymorphic regions (Table 1). No significant differences among breeds were found regarding intron 1 (12-bp indel; $P>0.01$, chi-square test), whereas significant differences among breeds were found in the promoter region $(P<0.01)$. All breeds were in Hardy-Weinberg equilibrium for both regions $(P>0.05)$. Likewise, no significant differences among breeds were found regarding alleles of intron $1(P>0.01)$, whereas significant differences among breeds were found regarding alleles of the promoter region $(P<0.01)$.

Genotype frequencies of $97.06 \%$ were found for haplotype $23 \mathrm{del} / \mathrm{del}$ in the Nellore breed. Allele frequencies of $79.41 \%$ were found for the 12 del in the Canchim Breed and frequencies of $80.77 \%, 79.41 \%$ and $98.53 \%$ were found for the 23 del in the Angus, Canchim and Nellore breeds, respectively (Table 1 ). 
Table 1. Genotype and allele frequencies of the indel PRNP of 12 and 23 bp

\begin{tabular}{|c|c|c|c|c|}
\hline Breeds (n) ${ }^{a}$ & Angus (26) & Canchim (17) & Nelore (34) & Simental (25) \\
\hline \multicolumn{5}{|c|}{ Genotype Frequencies } \\
\hline \multicolumn{5}{|c|}{$12 \mathrm{bp}(400 / 412 \mathrm{bp})^{\mathrm{b}}$} \\
\hline ins/ins & $26.92 \%$ & $0 \%$ & $11.76 \%$ & $12 \%$ \\
\hline del/del & $19.23 \%$ & $58.82 \%$ & $35.29 \%$ & $28 \%$ \\
\hline ins/del & $53.85 \%$ & $41.18 \%$ & $52.94 \%$ & $60 \%$ \\
\hline H-WEd $(P)^{f}$ & $0.18(>0.05)$ & $1.14(>0.05)$ & $0.50(>0.05)$ & $3.12(>0.05)$ \\
\hline$X^{2}$ e $(P)$ & $11.58(>0.01)$ & & & \\
\hline \multicolumn{5}{|c|}{$23 b p(393 / 416 b p)^{c}$} \\
\hline ins/ins & $7.69 \%$ & $5.88 \%$ & $0 \%$ & $8 \%$ \\
\hline $\mathrm{del} / \mathrm{del}$ & $69.23 \%$ & $64.71 \%$ & $97.06 \%$ & $40 \%$ \\
\hline ins/del & $23.08 \%$ & $29.41 \%$ & $2.49 \%$ & $52 \%$ \\
\hline H-WE (P) & $1.72(>0.05)$ & $0.17(>0.05)$ & $0.01(>0.05)$ & $0.63(>0.05)$ \\
\hline $\mathrm{X}^{2}(\mathrm{P})$ & $23.73(<0.01)$ & & & \\
\hline \multicolumn{5}{|c|}{ Allele Frequencies } \\
\hline \multicolumn{5}{|l|}{$12 \mathrm{bp}$} \\
\hline Ins & $53.85 \%$ & $20.59 \%$ & $38.24 \%$ & $42 \%$ \\
\hline Del & $46.15 \%$ & $79.41 \%$ & $61.76 \%$ & $58 \%$ \\
\hline$X^{2}(P)$ & $9.64(>0.01)$ & & & \\
\hline \multicolumn{5}{|l|}{$23 \mathrm{bp}$} \\
\hline ins & $19.23 \%$ & $20.59 \%$ & $1.47 \%$ & $34 \%$ \\
\hline del & $80.77 \%$ & $79.41 \%$ & $98.53 \%$ & $66 \%$ \\
\hline$X^{2}(P)$ & $22.19(<0.01)$ & & & \\
\hline
\end{tabular}

${ }^{a}$ Number of animals from each breed; ${ }^{b}$ size of fragment amplified in intron 1 (400 are fragments with deletion of nucleotides and 412 are fragments with insertion of nucleotides); ${ }^{c}$ size of fragment amplified in promoter region (393 are fragments with deletion of nucleotides and 416 are fragments with insertion of nucleotides); ${ }^{\mathrm{d}}$ Hardy-Weinberg equilibrium test; ${ }^{\mathrm{e}}$ chi-square test; ${ }^{\mathrm{f}}$ significance level.

Table 2. Frequency of dyplotypes of indel PRNP of 12 and $23 \mathrm{bp}$

\begin{tabular}{|c|c|c|c|c|c|c|c|c|c|c|c|c|}
\hline \multirow{2}{*}{$\begin{array}{l}\text { Breeds }(2 n)^{a} \\
\text { Dyplotypes }\end{array}$} & \multicolumn{3}{|c|}{ Angus (26) } & \multicolumn{3}{|c|}{ Canchim (17) } & \multicolumn{3}{|c|}{ Nelore (34) } & \multicolumn{3}{|c|}{ Simental (25) } \\
\hline & $\mathrm{Ob}$ & Ec & $\mathrm{F} \%{ }^{\mathrm{d}}$ & 0 & $\mathrm{E}$ & $\mathrm{F} \%$ & 0 & $\mathrm{E}$ & $\mathrm{F} \%$ & 0 & $\mathrm{E}$ & F\% \\
\hline $12 \mathrm{del} .23 \mathrm{del} / 12 \mathrm{del} .23 \mathrm{del}$ & 3 & 0 & 12 & 5 & 0 & 29 & 12 & 0 & 35.29 & 5 & 0 & 20 \\
\hline $12 \mathrm{ins} .23 \mathrm{del} / 12 \mathrm{ins} .23 \mathrm{del}$ & 4 & 0 & 15 & 0 & 0 & 0 & 3 & 0 & 8.82 & 1 & 0 & 4 \\
\hline 12ins.23ins/12ins.23del & 2 & 0 & 8 & 0 & 0 & 0 & 1 & 0 & 2.94 & 1 & 0 & 4 \\
\hline $12 \mathrm{ins} .23 \mathrm{del} / 12 \mathrm{del} .23 \mathrm{del}$ & 11 & 0 & 42 & 9 & 0 & 53 & 18 & 0 & 52.94 & 4 & 0 & 16 \\
\hline 12ins.23ins/12ins.23ins & 1 & 0 & 4 & 0 & 0 & 0 & 0 & 0 & 0 & 1 & 0 & 4 \\
\hline 12del.23ins/12del.23ins & 1 & 0 & 4 & 1 & 0 & 5.9 & 0 & 0 & 0 & 1 & 0 & 4 \\
\hline 12del.23ins/12del.23del & 1 & 0 & 4 & 1 & 0 & 5.9 & 0 & 0 & 0 & 1 & 0 & 4 \\
\hline 12ins.23ins/12del.23del & 0 & 2 & 8 & 0 & 0 & 0 & 0 & 0 & 0 & 0 & 7.5 & 30 \\
\hline 12ins.23del/12del.23ins & 0 & 1 & 4 & 0 & 1 & 5.9 & 0 & 0 & 0 & 0 & 3.5 & 14 \\
\hline
\end{tabular}

Table 3. Frequency of haplotypes of indel PRNP of 12 and 23 bp

\begin{tabular}{lcccccccccccc}
\hline Breeds (n) & \multicolumn{4}{c}{ Angus (52) } & \multicolumn{3}{c}{ Canchim (34) } & \multicolumn{3}{c}{ Nelore (68) } & \multicolumn{3}{c}{ Simental (50) } \\
Haplotypes & Ob & Ec & F\% ${ }^{\mathrm{d}}$ & O & E & F\% & O & E & F\% & O & E & F \% \\
\hline 12del.23del & 18 & 2 & 38.5 & 20 & 0 & 58.8 & 42 & 0 & 61.76 & 15 & 7.5 & 45 \\
12ins.23del & 21 & 1 & 42.3 & 6 & 1 & 20.6 & 26 & 0 & 38.24 & 7 & 3.5 & 21 \\
12ins.23ins & 4 & 2 & 11.5 & 0 & 0 & 0 & 0 & 0 & 0 & 3 & 7.5 & 21 \\
12del.23ins & 3 & 1 & 7.7 & 6 & 1 & 20.6 & 0 & 0 & 0 & 3 & 3.5 & 13 \\
D'e & 0.1319 & 1 & 0 & 0.3408 & & & & & & & & \\
rf & 0.0596 & 0,260 & 0 & 0.2874 & & & & & & & &
\end{tabular}

a Number of chromosomes with haplotypes; ${ }^{\text {b }}$ observed chromosomes; ${ }^{\mathrm{c}}$ chromosomes estimated from pairs of chromosomes for animals with double-heterozygous genotype; ${ }^{d}$ percentage frequency; ${ }^{\mathrm{e}}$ linkage disequilibrium,${ }^{\mathrm{f}}$ correlation

The genotype and allele frequencies were calculated using the analysis of the electrophoresis profile of each animal in agarose gel for both polymorphic regions (Table 1). No significant differences among breeds were found regarding intron 1 (12-bp indel; $P>0.01$, chi-square test), where- as significant differences among breeds were found in the promoter region $(P<0.01)$. All breeds were in Hardy-Weinberg equilibrium for both regions $(P>0.05)$. Likewise, no significant differences among breeds were found regarding alleles of intron $1(P>0.01)$, whereas significant differences 
among breeds were found regarding alleles of the promoter region $(P<0.01)$.

Genotype frequencies of $97.06 \%$ were found for haplotype $23 \mathrm{del} / \mathrm{del}$ in the Nellore breed. Allele frequencies of $79.41 \%$ were found for the 12 del in the Canchim Breed and frequencies of $80.77 \%, 79.41 \%$ and $98.53 \%$ were found for the 23 del in the Angus, Canchim and Nellore breeds, respectively (Table 1).

With the genotype data for each animal, it was possible to understand the formation of diplotypes and calculate the respective frequencies (Table 2). The numbers of estimated diplotypes from animals with double-heterozygote genotypes are displayed in Table 2.

Table 3 displays the data obtained from the frequency of haplotypes for each breed and the estimated number of haplotypes. The estimates came from the diplotypes of double-heterozygous animals.

\section{DISCUSSION}

The electrophoresis in 3\% agarose gel of the PCR amplification product of the target regions studied is an important tool for the detection of genotypes of interest. Through visualization the difference in molecular weight of the fragments in agarose gel $3 \%$ was possible to identify the insertion and/or deletion of 12 or $23 \mathrm{pb}$ and the determination of homozygous genotypes correlated with resistance and BSE (ins/ins), homozygous correlated with susceptibility susceptible to BSE (del/del) and heterozygous (ins/del (Fig. 3). Identical information about the genotypic profile of the samples were observed in electropherograms obtained by sequencing, which highlights the efficiency and reliability of PCR and electrophoresis on 3\% agarose gel for genotyping and analysis of polymorphisms in these regions of the PRNP gene (Fig.4 and Fig.5). Genotyping can also be performed by real-time PCR (Jor et al. 2010) or even by means of mass spectrometry, however these methods show is expensive when compared to conventional PCR coupled with agarose gel electrophoresis and these techniques have equivalent efficiency to conventional PCR and Sanger sequencing.

The insertion genotypes for 12-bp in intron 1 and 23bp in the promoter region are of considerable importance. The Angus breed had the highest frequency of the insertion genotype for $12 \mathrm{bp}$. The Canchim breed exhibited a high frequency of the deletion genotype of 12-bp. Regarding the indel region of 23-bp, the Angus, Canchim and Nellore breeds exhibited high frequencies of the deletion genotype (Table 1).

Tests with the gene containing the indels of 12-bp and 23-bp were performed in vitro and in vivo. The in vitro test showed that the cells containing the deletion genotype, particularly 23-bp, expressed $\mathrm{PrP}^{\mathrm{sc}}$ in high quantities. In the in vivo test performed with calves, high expression of the protein was found in the intestinal lymph nodes.

Dairy cattle from Vietnam have exhibited a high frequency of the homozygous genotype of deletion for 23-bp in the promoter region. This country imports meat and bone meal for feeding dairy cattle. Konold et al. (2012) demonstrated that cattle exposed to meal containing the brain stem of animals infected with BSE develop the disease. Bovines from Turkey have a high frequency of the heterozygous 23-bp genotype and the 12-bp insertion genotype (Un et al. 2008). The heterozygous genotypes for 23-bp and 12-bp were the most frequent in a study with Holstein-Friesian bovines from Poland (Czarnik et al. 2011). Thus, 23-bp alterations in the promoter region of the gene and 12-bp alterations in intron 1 may be important, as these are considered regulatory sites responsible for the negative feedback of the expression of the prion protein in cattle (Xue et al. 2012a, 2012b).

The deletion alleles of 12-bp and 23-bp are in the intron 1 and promoter region, respectively, and are associated with susceptibility to the development of BSE. This was proven when a study was made with bovine breeds from Germany and Switzerland comparing healthy and sick animals with BSE (Haase et al. 2007).

In the present study, only the Angus breed had a higher frequency for the 12 ins allele $(53.85 \%)$ than 12 del allele (46.15\%) (Table 1). The opposite occurred in another study with the Angus breed, in which a higher frequency was found for the 12 del allele (56\%) and a lower frequency was found for the $12 \mathrm{ins}$ allele (44\%). In the analysis of the promoter region, the four breeds exhibited higher frequencies for the 23del allele in comparison to the 23ins allele. A frequency of $98.53 \%$ was found for the $23 \mathrm{del}$ allele in the Nellore breed (Table 1).

The Kuchinoshima breed of Japanese origin, has exhibited a frequency of $100 \%$ for the $12 \mathrm{del}$ and $23 \mathrm{del}$ alleles. The Holstein-Friesian breed from Poland has exhibited a frequency of $53.3 \%$ for the $12 \mathrm{del}$ allele and $63.6 \%$ for the 23 del allele. A number of bovines from Slovakia affected by BSE were compared to healthy animals, but no significant differences were found between the frequencies for the deletion alleles in intron 1 and the promoter region: healthy animals exhibited $63.6 \%$ for $23 \mathrm{del}$ and $56.5 \%$ for $12 \mathrm{del}$; animals stricken by the disease exhibited $70.8 \%$ for $23 \mathrm{del}$ and $64.6 \%$ for $12 \mathrm{del}$. High frequencies of heterozygous genotypes were found for both regions in this particular study. Bovines of Pakistani breeds have exhibited a high frequency of the 12ins allele (94.07\%) (Imran et al. 2012). Another bovine representative, the mithun (Bos frontalis), which is the domesticated form of the Asian gaur, has exhibited high allele frequencies of 12ins (77\%) and 23ins (82\%). The Anatolian buffalo (Bubalus bubalis) has also exhibited high allele insertion frequencies: $86 \%$ for and $92 \%$ for 23 ins.

The Nellore breed is of Indian origin (Bos indicus) and differs from the Angus and Simmental breeds, which that have a European origin (Bos taurus). A comparative study of these polymorphisms in the PRNP gene revealed that Bos indicus exhibits a higher frequency of the 23del allele (88\%) than Bos taurus (62\%) (Brunelle et al. 2008). According to Brunelle et al. (2008), the origin of these polymorphisms may be Indian cattle, since these animals enter the training or breeding programs of some European breeds. However, a study has demonstrated that the European Bison (Bison bonasus), which also belongs to the Bovidae family, exhibited a frequency of $100 \%$ for $23 \mathrm{del}$ and $100 \%$ for the $12 \mathrm{ins}$ 
allele (Czarnik et al. 2009). It is important to obtain results from other members of the bovine family to raise other hypotheses that seek to explain the origin of these polymorphisms, whether they involve insertion or deletion in the bovine PRNP gene.

Bovines of mixed breeds, that is, those that are formed by a combination of Bos taurus and Bos indicus, have exhibited frequencies of $47 \%$ and $53 \%$ for the 12 ins and $12 \mathrm{del}$ alleles, respectively, and $20 \%$ and $80 \%$ for the 23ins and $23 d$ del alleles, respectively (Brunelle et al. 2008). The Canchim breed is reared in Brazil and contains breeds of European and Indian origin. The frequencies recorded for this breed were equal: $20.59 \%$ for 12 ins and 23 insand $79.41 \%$ for $12 \mathrm{del}$ and $23 \mathrm{del}$ (Table 1). A probable contribution of Bos indicus deletion alleles may be acting on these representatives of the Canchim breed.

Knowledge of common breeds or ancestors who contributed to the genetic constitution of genotyped races are important as they may direct the use of these animals for future breeding. This knowledge also helps in understanding the genotypic frequencies of indels $23-\mathrm{pb}$ and $12-\mathrm{pb}$ identified in these animals, especially taking into consideration the coefficient of relationship between them. Currently, strains bull Kavardi along with their descendants (Chumak, Gim de Garça and Ludy de Garça) and families of bulls Taj Mahal I demonstrate strong influence on the population of Nellore crossbred (including Canchin) animals and in Brazil which may have contributed to the genotypic constitution presented by these animals and that may be correlated with increased genetic susceptibility to BSE.

Polymorphisms in chromosome pairs were analyzed in the diplotypes. The Angus and Simental breeds each exhibited a frequency of $4 \%$ for the 12ins-23ins/12ins-23ins diplotype, demonstrating 12 and 23bp insertions in both alleles or both chromosomes (Table 2). The Aberdeen Angus, Charolais and Franqueiro breeds exhibited frequencies of $3 \%, 10 \%$ and $16 \%$, respectively, for the diplotype. In Holstein breeds from the United Kingdom and Germany, as well as the German Brown and Fleckvieh breeds, the frequencies recorded in healthy animals were 5\%, 15\%, 46\% and $11 \%$, respectively (Juling et al. 2006).

Japanese cattle in which the messenger RNA transcription rate was evaluated and which exhibited the 12 del-23del/12del-23del diplotype demonstrated higher PrP expression in comparison to diplotypes consisting of 12-bp and 23-bp insertions in the promoter region and intron 1, respectively (Msalya et al. 2011). In the present study, the Nelore breed exhibited a higher frequency of the 12del-23del/12del-23del diplotype (35.39\%) and genotype frequencies in the indel 12 region, but no statistically significant differences were found among the breeds analyzed ( $p>0.05 \%$ ). The 12ins-23del/12del-23del diplotype was found at greater frequencies in all breeds in comparison to the $12 \mathrm{del}-23 \mathrm{del} / 12 \mathrm{del}-23 \mathrm{del}$ diploytype and was highest in the Canchim breed (53\%). Genotype frequencies of the indel 23 region differed significantly among the breeds $(\mathrm{p}<0.05 \%)$.

The haplotypes found in the present study indicate two changes that may occur simultaneously in the same allele (12-bp indel and 23-bp indel). Knowledge on the frequencies and linkage disequilibrium that occurs between these two changes may be important to the understanding of how these haplotypes are segregated in future generations. In the present study, only the Angus and Simental breeds exhibited the 12ins.23ins haplotype, demonstrating the possibility of simultaneous segregation (Table 3 ).

The same haplotype has appeared in Korean cattle with a frequency that corresponded to the frequency of healthy cattle in Germany. In another study with Korean cattle of the Hanwoo breed, the frequency for healthy animals was $42 \%$ (Choi et al. 2012), whereas cattle from Poland exhibited a frequency of 36.3\% (Gurgul et al. 2012). The Turkish Gray breed exhibited a haplotype frequency (12ins.23ins) of $62 \%$, which was higher than the frequency of healthy Korean and German cattle (Un et al. 2008).

Further studies on the indels in intron 1 and the promoter region of the PRNP gene in cattle are currently underway. The understanding of how these indels influence PrP synthesis in cattle may help clarify the mechanism that triggers the synthesis of the infectious protein.

From the detailing of the main polymorphisms in intron 1 and the promoter region in representatives of cattle breeds reared in Brazil, it was possible to determine the profile of the PRNP gene in these animals. Further studies are required to enable a better understanding of the genotype profile of the gene in these and other breeds, which currently make up breeding programs and contribute significantly to the development of the meat production chain.

Acknowledgements.- The authors would like to thank Embrapa Beef Cattle for the allowing the use of the laboratories, doctors Luciana Regitano and Fabiane Siqueira for providing the DNA samples and the Brazilian fostering agencies $\mathrm{CNPq}$ and Finep for the study grant and project financing.

\section{REFERENCES}

Aguzzi A., Nuvolone M. \& Zhu C. 2013. The immunobiology of prion diseases. Nature Revs Immunol. 13(12):888-902.

Brunelle B.W., Greenlee J.J., Seabury C.M., Brown C.E. \& Nicholson E.M. 2008. Frequencies of polymorphisms associated with BSE resistance differ significantly between Bos taurus, Bos indicus, and composite cattle. BMC Vet. Res. 4:36.

Choi S., Woo H.J. \& Lee J. 2012. Sequence variations of the bovine prion protein gene (PRNP) in native Korean Hanwoo cattle. J. Vet. Sci. 13:127-137.

Czarnik U., Zabolewicz T., Strychalski J., Grzybowski G., Bogusz M. \& Walawski K. 2007. Deletion/insertion polymorphism of the prion protein gene (PRNP) in polish holstein-friesian cattle. J. Appl. Genet. 48:69-71.

Czarnik U., Grzybowski G., Zabolewicz T., Strychalski J. \& Kaminski S. 2009. Deletion/insertion polymorphism of the prion protein gene (PRNP) in Polish red cattle, Polish White-backed cattle and European bison (Bison bonasus L., 1758). Genetika 45:519-525.

Czarnik U., Strychalski J., Zabolewicz T. \& Pareek C.S. 2011. Population wide investigation of two indel polymorphisms at the prion protein gene in Polish Holstein-Friesian cattle. Biochem. Genet. 49:303-312.

Galvão C.E., Rosinha G.M.S., Sanches C.C., Elisei C., Araújo F.R., Feijó G.L.D. \& Soares C.O. 2012. Polymorphisms of intron 1 and the promoter region at the PRNP gene in BSE-free Caracu cattle. Biochem. Genetics 50:657-669.

Gurgul A., Czarnik U., Larska M., Polak M.P., Strychalski J. \& Slota E. 2012. Polymorphism of the prion protein gene (PRNP) in Polish cattle affected by classical bovine spongiform encephalopathy. Mol. Biol. Rep. 39:5211-5217.

Haase B., Doherr M.G., Seuberlich T., Drogemuller C., Dolf G., Nicken P., Schiebel K., Ziegler U., Groschup M.H., Zurbriggen A. \& Leeb T. 2007. 
PRNP promoter polymorphisms are associated with BSE susceptibility in Swiss and German cattle. BMC Genet. 8:15.

Haigh C.L., Wright J. \& Brown D.R. 2007. Regulation of prion protein expression by noncoding regions of the Prnp gene. J. Mol. Biol. 368(4):915-927.

Holznagel E., Yutzy B., Schulz-Schaeffer W., Kruip C., Hahmann U., Bierke P. \& Loewer J. 2013. Foodborne transmission of bovine spongiform encephalopathy to nonhuman primates. Emerg. Infect. Dis. 19:712-720.

Imran M., Mahmood S., Babar M.E., Hussain R., Yousaf M.Z., Abid N.B. \& Lone K.P. 2012. PRNP gene variation in Pakistani cattle and buffaloes. Gene 505:180-185.

Juling K., Schwarzenbacher H., Williams J.L. \& Fries R. 2006. A major genetic component of BSE susceptibility. BMC Biol. 4:33.

Jor E., Myrmel M. \& Jonassen C.M. 2010. SYBR Green based real-time RT-PCR assay for detection and genotype prediction of bovine noroviruses and assessment of clinical significance in Norway. J. Virol. Methods 169:1-7

Konold T., Bone G.E., Clifford D., Chaplin M.J., Cawthraw S., Stack M. \& Simmons M.M. 2012. Experimental H-type and L-type bovine spongiform encephalopathy in cattle: observation of two clinical syndromes and diagnostic challenges. BMC Vet. Res. 8(1):22.

Msalya G., Shimogiri T., Ohno S., Okamoto S., Kawabe K., Minezawa M. \& Maeda Y. 2011. Evaluation of PRNP expression based on genotypes and alleles of two indel loci in the medulla oblongata of Japanese Black and Japanese Brown cattle. PloS One 6(5):18787.

Olerup 0. \& Zetterquist H. 1992. HLA-DR typing by PCR amplification with sequence-specific primers (PCR-SSCP) in 2 hours: An alternative to serological DR typing in clinical practice including donor-recipient matching in cadaveric transplantation. Tissue Antigens, 39:225-235.

Un C., Oztabak K., Ozdemir N., Tesfaye D., Mengi A. \& Schellander K. 2008. Detection of bovine spongiform encephalopathy-related prion protein gene promoter polymorphisms in local Turkish cattle. Biochem. Genet. 46:820-827.

Xue G., Aida Y., Onodera T. \& Sakudo A. 2012a. The 5' flanking region and intron1 of the bovine prion protein gene (PRNP) are responsible for negative feedback regulation of the prion protein. PloS One 7:32870.

Xue G., Sakudo A., Kim C.K. \& Onodera T. 2012b. Coordinate regulation of bovine prion protein gene promoter activity by two Sp1 binding site polymorphisms. Biochem. Biophys. Res. Commun. 372:530-535.

Wells G.A., Scott A.C., Johnson C.T., Gunning R.F., Hancock R.D., Jeffrey M., Dawson M. \& Bradley R. 1987. A novel progressive spongiform encephalopathy in cattle. Vet. Rec. 121:419-420.

Zadworny D. \& Kuhnlein U. 1990. The identification of the kappa-casein genotype in Holstein dairy cattle using the polymerase chain reaction. Theor. Appl. Genet. 80:631-634. 